\title{
EARLY DEVONIAN GRAPTOLITES FROM TASMANIA
}

\author{
by M. R. Banks and R. B. Rickards
}

(with one table, three text-figures and one plate)

BANKS, M. R. and RICKARDS, R.B.,1989 (31:x): Early Devonian graptolites from Tasmania. Pap. Proc. R. Soc. Tasm. 123: 111-117. https://doi.org/10.26749/rstpp.123.111 ISSN 0080-4703. Department of Geology, University of Tasmania, GPO Box 252C, Hobart, Tasmania, Australia 7001 (MRB); Department of Earth Sciences, University of Cambridge, Downing Street, Cambridge CB2 3EQ, UK (RBR).

Monograptus thomasi Jaeger occurs in siltstone just east of Flowery Gully in northern Tasmania and indicates an early Devonian age for the host rocks.

Key Words: Devonian, graptolites, Tasmania, Monograptus.

\section{INTRODUCTION}

Monograptus aequabilis cf. notoaequabilis Jaeger \& Stein, 1969 has recently been reported from the Mathinna Beds near Scamander in northeastern Tasmania (Rickards \& Banks 1979). Late in February 1983, a group of students (S. Capp, J. Lea, A. Tidswell and N. Wright) found Monograptus in medium to dark-grey slaty siltstones on Bulls Road, east of Flowery Gully (146 $\left.50^{\prime} \mathrm{E}, 41^{\circ} 16^{\prime} \mathrm{S}\right)$. They found graptolites at two localities near the same road junction (universal grid reference Zone 55G DQ 8569.3165; Tasmanian 1:100 000 map series Tamar 8215), one $44 \mathrm{~m}$ down the road to the southwest and the other $92 \mathrm{~m}$ up the road to the south (fig. 1). Subsequently graptolites were also found $28 \mathrm{~m}$ and $54 \mathrm{~m}$ up the road to the south. It is clear that graptolites occur on at least three horizons, as the siltstone has a fairly constant dip to the north-northeast. The $92 \mathrm{~m}$ locality on the upper road and the $44 \mathrm{~m}$ locality on the lower road are probably on the same horizon. The graptolitic horizons occur within about $30 \mathrm{~m}$ stratigraphically of one another. On the same bedding surfaces as the graptolites and also stratigraphically below are poorly-preserved plant remains, both stems and elliptical bodies (probably sporangia).

\section{STRATIGRAPHY AND AGE}

The lowest graptolitic bed lies, at most, $85 \mathrm{~m}$ stratigraphically below a bed with bivalves (e.g. Praecardium sp.), orthoconic cephalopods, rare trilobites (phacopids) and extremely abundant dacryoconarids. The presence of $\boldsymbol{M}$. thomasi Jaeger shows this particular part of the sequence to be early Devonian in age. In the Melborne Trough in Victoria, $M$. thomasi is restricted to the Wilson Creek Shale and its equivalents (e.g. Killingworth Formation), and is the nominal species for the $\boldsymbol{M}$. thomasi Assemblage Zone of Pragian age (Garratt 1983). The level of the $M$. thomasi Zone in the Pragian was discussed in the same paper but there are apparently some biostratigraphical anomalies yet to be resolved; provisionally Garratt (1983: 81) regarded the $M$. thomasi Zone as early Pragian.

\section{IMPLICATIONS}

The association of $\boldsymbol{M}$. thomasi with plants occurs both at Flowery Gully and in the Melbourne Trough in Victoria, but the Tasmanian plant material cannot yet be identified. In the Melboume Trough, $M$. thomasi occurs below $M$. aequabilis notoaequabilis for the most part, but the species overlap in the top part of the Wilson Creek Shale (Garratt 1983). 


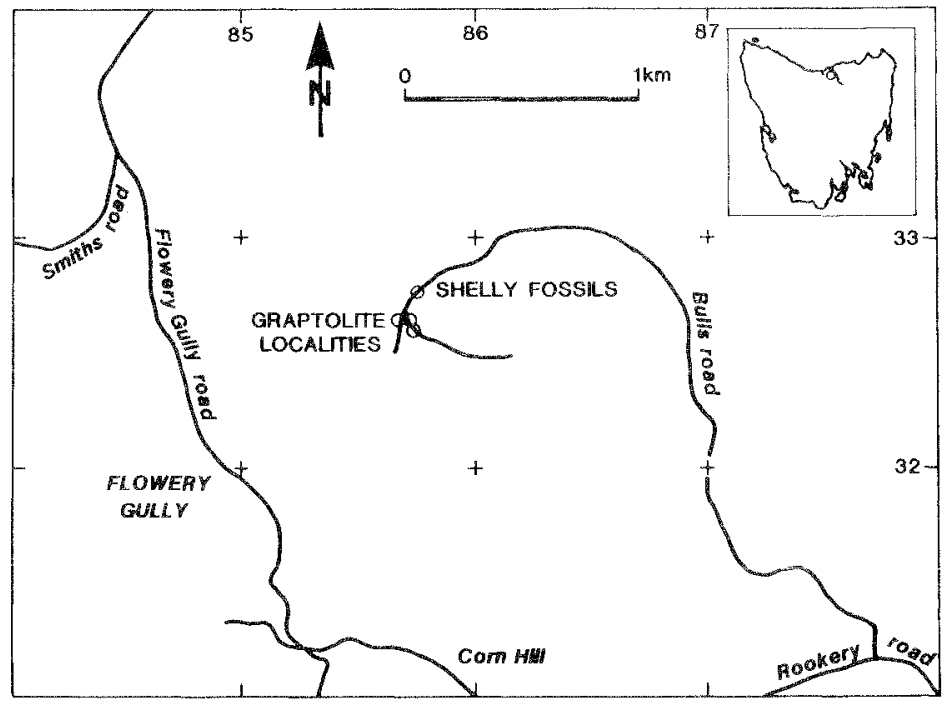

FIG. 1 - Locality map

Rickards \& Banks (1979) have reported $M$. aequabilis cf. notoaequabilis from the Mathinna Beds near Scamander in northeastern Tasmania. The graptolitic beds east of Flowery Gully are thus of the same age as or slightly older than the graptolitic beds in the Mathinna Beds at Scamander.

\section{SYSTEMATIC PALAEONTOLOGY}

Genus Monograptus Geinitz 1852 Monograptus thomasi Jaeger 1966 Figs 2, 3; pl. 1

1906 Monograptus dubius Suess; T.S. Hall 1906, 267, fig. 3 .

?1906 M. cf. dubius Suess; T.S. Hall 1906, 268.

?1906 M. sp. T.S. Hall 1906, 268.

?1907 $M$. cf. dubius Suess; T.S. Hall 1907 , 140-141.

?1907 M. cf. crenulatus (Tornquist); T.S.Hall 1907, 140-141.

?1907 M. sp. (colonus group); T.S.Hall 1907, 140-141.

?1925 M. dubius et al.; Baragwanath, 21-22.

1933 Monograptus riccartonensis Lapworth; Keble, 293, pl.

1935 Monograptus uncinatus var. orbatus Wood; Elles, in Lang \& Cookson, 422, pl. 32, figs $51-53$.

1935 Monograptus uncinatus var. microspora (sic)(Jaekel); Elles, in Lang \& Cookson, 422.
1935 Monograptus chimaera (Barrande); Elles, in Lang \& Cookson, 422.

1935 Monograptus galaensis Lapworth; ex Monograptus cf. galaensis Lapworth, Thomas identification, in Lang \& Cookson, 422.

1937 Monograptus uncinatus var. orbatus Wood; Harris \& Thomas, 69--73, pl. 2, figs 23-25, ?26, 27-28, non 29.

?1937 M. uncinatus var. micropoma (Jaekel); Harris \& Thomas, 69, 73-74, pl. 2, fig. 30.

1960 M. uncinatus var. orbatus Wood; Thomas, fig. 187.

1964 Monograptus sp. nov. (of the $M$. hercynicus type) forma A and B; Berry, 9-13, fig. 1a, b, pls 1-2.

1966 Monograptus thomasi n.sp.; Jaeger 1966, $403-411$, pl. 41 , figs $3-5$; pl. 42 , figs $2-7$; pl. 43, figs $1 \mathrm{a}-\mathrm{c}$, $\mathrm{o}$.

1970 Monograptus thomasi Jaeger; Jaeger 1970 , 175-180.

1971a Monograptus thomasi Jaeger; Lenz \& Jackson, 13-14, pl. 2, figs 1-4, text-figs 3A, B, H, I.

?1971b Monograptus cf. thomasi; Lenz and Jackson, 131.

1973 Monograptus thomasi Jaeger; Jaeger 1973, 107, fig. In.

1975 Monograptus thomasi Jaeger; Mu \& Ni Yunan, 22--24; pl.7, figs $1-4,8-11$; pl. 8 , figs $8 \mathrm{~b}, 30$.

1977 M. thomasi ; Wang Xiao-feng 1977, 196. table 1.

1978 Monograptus thomasi Jaeger; Jackson, Lenz and Pedder, pl. 4, fig. 5. 


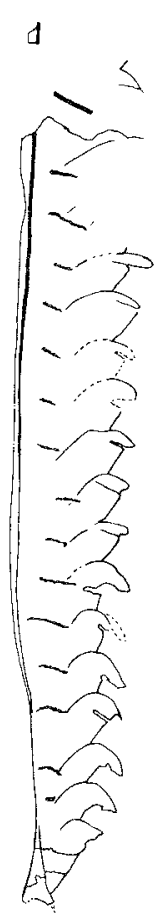

A

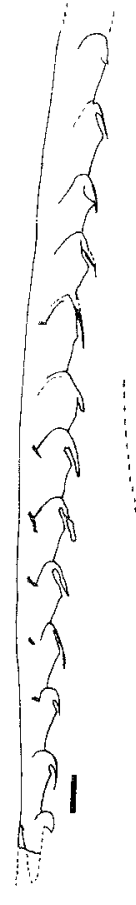

B

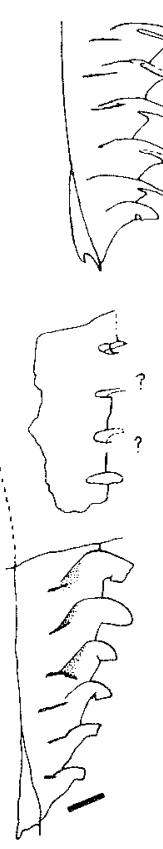

C

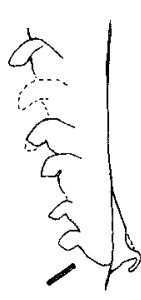

E

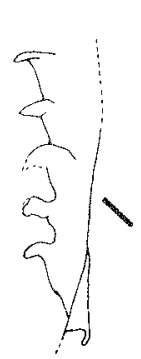

$\mathrm{F}$

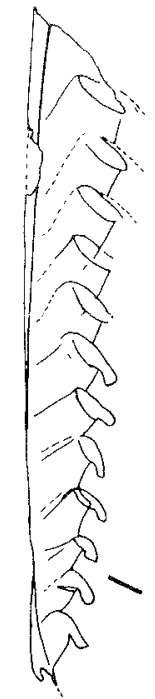

G

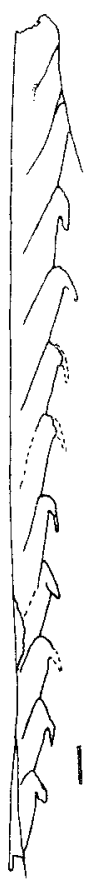

$\mathrm{H}$

FIG. 2 - Monograptus thomasi Jaeger, Bulls Road, east of Flowery Gully, Tasmania; all x5; black bars indicate tectonic stretching direction: (A) stipe showing dorsal curvature, nema, sicula and hooded thecae, UTGD $121987(b, v i) ;(B)$ stipe showing tendency for thecae to develop proximo-ventrally directed spines, UTGD 121997; (C) sicular end of stipe showing sicula, UTGD I21987(b, iv); (D) proximal end of most deformed specimen showing "added on" sicula and proximal, hooded thecae and dorsal tongue, UTGD 121987(a,i); (E) proximal end showing sicula with dorsal tongue, hooded proximal thecae, UTGD 121987(a, viii); ( $F)$ proximal end showing dorsal curvature, sicula with dorsal tongue, trace of virgella and hooded proximal thecae, UTGD 122347(a); $(G)$ a stipe oriented at a high angle to " $b$ ", the stretching direction; $N . B$. stipe width, ventrally curved dorsal tongue and virgella, UTGD 123762b; $(H)$ a stipe oriented parallel to " $b$ "; N.B. stipe width, straightness of sicula, dorsal tongue and virgella, UTGD $123762 a$.

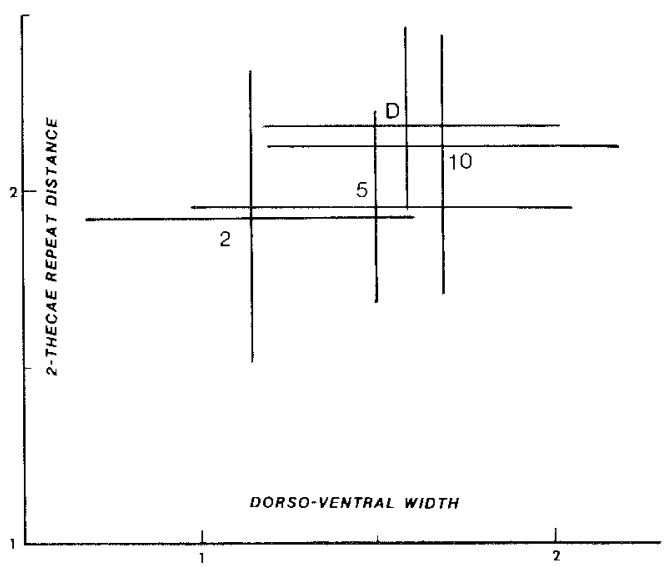

FIG. 3 - Monograptus thomasi Jaeger, Bulls Road, east of Flowery Gully, northern Tasmania. Graph showing the mean and standard deviation of two thecae repeat distance against ventral width at th2, th5, thlo and distal theca $(D)$; measurements in millimetres. 


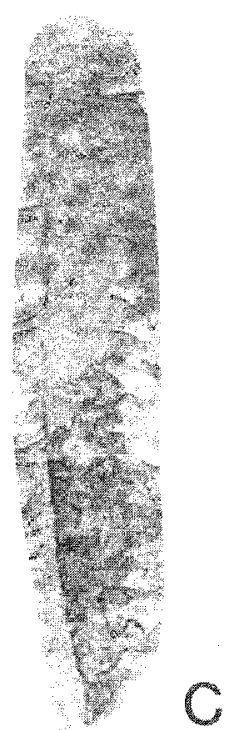

A

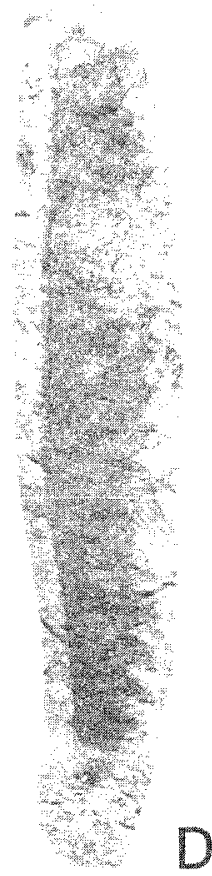

PLATE 1

Monograptus thomasi Jaeger, Bulls Road, east of Flowery Gully, northern Tasmania: (A) stipe showing curvature and thecal shapes; proximal part unstained, distal part iron-stained, UTGD $123613, \times 2.5$;

(B) stipe showing thecal shape, dorsal curvature and effects of deformation, UTGD 123762a, $\times 3.75$;

(C) stipe showing some details of proximal end and thecal shape, UTGD 121987 b(iii), $\times 4$;

(D) stipe showing dorsal curvature and some proximal thecae, UTGD 121987 b(iv), $\times 7.5$.

1979 Monograptus thomasi ; Koren', 99-100, fig. 5.4 .

1980 Monograptus thomasi ; Wang Xiao-feng 1980, chart 2, fig. 2.

1984 Monograptus thomasi Jaeger; Porebska, 113, 174, fig. 7.

1984 Monograptus thomasi Jaeger; Garratt \& Rickards, fig. 8E.

1985 Monograptus thomasi Jaeger; Ni Yu-nan, 7; pl.3, fig. 6; pl.4, figs 3,6.

1987 Monograptus thomasi Jaeger; Garratt \& Rickards, fig. $2 \mathrm{i}$.

1988 Monograptus thomasi thomasi Jaeger; Jaeger, 433, fig. Q.

\section{Material and Preservation}

Several hundred rhabdosomes were studied, mostly from the $44 \mathrm{~m}$ locality, about 40 having preserved proximal ends. Preservation is as micaceous, muddy infills or as external moulds picked out lightly in ferruginous material in medium to dark grey siltstones, some of which are slates. Cleavages are at $30^{\circ}-60^{\circ}$ to the bedding, the latter often being emphasised by paler, coarser silt. There is some preferred orientation of rhabdosomes (e.g. UTGD 121987, 122327, 122337). The specimens are deformed by the development of cleavage and in the description below the measurements given first are the corrected figures (or of specimens lying at $45^{\circ}$ to the intersection lineation $B$ of cleavage on the bedding, which is the tectonic $b$ axis); the figures in brackets, following those for each 
dimension, indicate the range of values caused by the deformation. All the material is deposited in the Department of Geology, University of Tasmania, slab nos. UTGD 121987-122001 at $92 \mathrm{~m}$; $122002-122035$ at $44 \mathrm{~m} ; 122325-122328$ at $28 \mathrm{~m}$; $122329-122340$ at $54 \mathrm{~m}$; $122341-122347$ at $92 \mathrm{~m} ; 123760-123799$ at $92 \mathrm{~m}$

\section{Diagnosis}

Rhabdosomes medium-sized, $30 \mathrm{~mm}$ long (20-50), more or less straight except for characteristic gentle double-curvature at proximal end involving thecae 4-11; thecae with hoods decreasing in size distally and more readily exposing the ventral part of the thecal aperture; first few thecae have a slight tendency to metathecal isolation; sicula conspicuously placed dorsally, with pronounced, incurved dorsal tongue; dorso-ventral width at th I' hood is about $1.0 \mathrm{~mm}(0.5-1.5 \mathrm{~mm})$; more distally is $1.8-2.1 \mathrm{~mm}(1.2-2.6 \mathrm{~mm})$; thecal spacing is $10-12$ over first few mm (8-15) and 9-10 distally to this $(6-13)$.

\section{Description}

The rhabdosome has a very characteristic curvature at the proximal end; the ventral margin of the rhabdosome remains almost straight but the dorsal margin bends sharply towards the ventral side in the region of th 4 -th 11 . There is, thus, a fairly rapid increase in dorso-ventral width at this point, and the overall aspect of the proximal end is one of gentle double-curvature and attenuation. With specimens at right angles to tectonic $b$ this feature is exaggerated, but the proximal end itself may appear relatively robust (figs $2 \mathrm{C}, \mathrm{D}, \mathrm{E}$ ). Those specimens lying parallel to tectonic $b$ have the characteristic curvature lessened, and the whole rhabdosome is typically slender. Specimens at $45^{\circ}$ to the lineation in $b$ are of a shape and dimension intermediate between the other two extremes, and they are probably close to the original (but flattened) dimensions of the graptolite.

The sicula is in a conspicuously dorsal position on the rhabdosome. Its apex reaches to between the hoods of th 1 and th 2, except in the most deformed specimens lying at right angles to the lineation (fig. 2D), where the thecae may have succumbed to deformation more than the sicula itself has been deformed. The sicular aperture has a short virgella and a very pronounced and incurved dorsal tongue (figs 2D,E,F,G).
The angle of growth of th 1 away from the sicula (i.e. its free ventral wall) is entirely dependent upon the direction of deformation (cf. figs $2 \mathrm{G}$ and $1 \mathrm{H}$ ) but th 1 is always as large as, or larger than th 2 and th 3 . All the thecae are hooded but the hood is less recurved in the distal thecae and the ventral apertural lip is usually visible beneath it: a slit is seen between the hood and the ventral apertural margin. In severely deformed specimens lying parallel to tectonic $b$, the hood may appear as a spine (fig. $2 \mathrm{H}$ ). The thecal spacing is $10-12$ over the first few mm $(8-15)$, the mean being a little over 10 ; more distally to this region the thecal spacing is fairly constant at 9-10 (6-13). The two thecae repeat distance (TTRD) increases from $1.92 \mathrm{~mm}\left(\right.$ TTRD $\left.^{2}\right)$ to $2.2 \mathrm{~mm}\left(\right.$ TTRD $^{\text {dist }}$ ).

Thecal overlap is always low but increases to about $1 / 3-1 / 2$ distally from a much smaller value at th 1 and th 2 . The base of the interthecal septum is often visible and is slightly thickened. The dorsoventral stipe width conspicuously reflects the tectonic deformation, especially on slabs with numerous randomly oriented specimens, those specimens at right angles to the lineation being very broad and those parallel to the lineation very narrow. Thus, at the level of the hood of th 1 the dorso-ventral width has a full range of $0.5-1.5 \mathrm{~mm}$, specimens at $45^{\circ}$ to the lineation most commonly being about $1.0 \mathrm{~mm}(0.80-1.30 \mathrm{~mm}$ is the full range measured when at $45^{\circ}$ to the lineation). The distal dorso-ventral width is $1.8-2.1 \mathrm{~mm}$ $(1.2-2.6 \mathrm{~mm})$, and the maximum may be reached in a few $\mathrm{mm}$ from the proximal end.

\section{Remarks}

When due allowances are made for tectonic deformation, the Flowery Gully specimens are remarkably close to the originals described by Jaeger (1966). The only slight differences are that th 1 is a fraction less conspicuous in its ventrodorsal extent relative to th 2 , and the thorn-like proximal aspect is possibly a little less pronounced than in the Victorian material. However, on both counts the Flowery Gully specimens match several of Jaeger's figured specimens (e.g. pl. 42 , figs 2,4 \& 5; pl. 43, left-hand specimen and the proximal end near the bottom of the plate). The Flowery Gully specimens are undoubtedly more deformed than those figured by Jaeger, but it is noticeable that the closest agreement (listed above) is with his tectonically deformed specimens (though in the text he does not give dimensions for these). Some of the deformation of the Flowery Gully specimens is 
TABLE 1

\section{Statistical Comparison of Tasmanian with Victorian Specimens of M. thomasi*}

\begin{tabular}{lccccc}
\hline & \multicolumn{5}{c}{ Two thecae repeat distance $(\mathrm{mm})$} \\
\cline { 2 - 6 } & $\mathrm{N}$ & Mean & $\mathrm{s}$ & $\mathrm{t}$ & $\mathrm{P}$ \\
\hline $\begin{array}{l}\text { Theca } 2 \\
\text { Tas. }\end{array}$ & 13 & 1.92 & 0.417 & & \\
Vic. & 5 & 1.82 & 0.183 & & \\
$\begin{array}{l}\text { Theca } 5 \\
\text { Tas. }\end{array}$ & 12 & 1.95 & 0.269 & & \\
$\begin{array}{l}\text { Vic. } \\
\text { Theca 10 }\end{array}$ & 5 & 1.94 & 0.361 & & \\
Tas. & 9 & 2.12 & 0.416 & & \\
$\begin{array}{l}\text { Vic. } \\
\text { Vistal theca }\end{array}$ & 4 & 2.1 & 0.324 & & \\
Tas. & 5 & 2.18 & 0.248 & & \\
Vic. & 2 & 2.05 & 0.05 & & \\
\hline
\end{tabular}

* Victorian specimens from Woods Point area;

Tasmanian specimens from Flowery Gully, in the collection of the Department of Geology, University of Tasmania.

$\mathrm{s}=$ standard deviation.

$t=$ the " $t$ statistic" of the two samples.

$\mathrm{P}=$ probability that the two samples are part of the same population.

of the type referred to by Jaeger (op. cit.: 404) where the greatest deformation is in petrofabric direction $a$, resulting in rather higher thecal spacings irrespective of angle to lineation $B$. TTRD measurement of similarly deformed Victorian specimens (table 1) shows a close resemblance between the two forms, although there is a little less correspondence when dorso-ventral width is considered.

The TTRDs for the collections from Tasmania and Victoria were statistically analysed (table 1). The two collections showed very strong correlations of TTRD at corresponding thecae and are, undoubtedly, on this basis the same species.
The final point to note in relation to the Victorian originals is that, whilst the thecal overlap of the Flowery Gully material compares well with the photographs of Jaeger (1966: pls 42, 43), they compare less well with his line drawings (figs $1 \mathrm{a}-\mathrm{c}$ ).

The characters of the proximal end distinguish $M$. thomasi from other species rather easily, only those severely deformed at right angles to lineation $B$ superficially resembling $M$. praeherynicus Jaeger and $M$. subhercynicus Willifert. Jaeger (op. cit.: 407-410, fig. 1) has given detailed comparisons with earlier described species, with which the authors concur. $M$. pacificus and $M$. craigensis differ from $M$. thomasi on thecal count, stipe width and proximal curvature. $M$. sudeticus Porebska has distinct ventral curvature proximally. $M$. telleri Lenz and Jackson is clearly quite close to $M$. thomasi, $M$. telleri telleri is rather narrower but with similar maximum dorso-ventral width and thecal spacing. The main difference between the two is the total lack of metathecal isolation in $M$. telleri. $M$. telleri zdanoviensis Porebska is a more robust sub-species with greater thecal overlap and thecal spacing than $M$. thomasi, but some late specimens recently figured by Porebska (1984: figs 22.21 and 22.22) have similar proximal curvature: Porebska (op . cit.) derived both $M$. craigensis and possibly $M$. thomasi from these late forms of $M$. $t$. zdanoviensis, near the base of the craigensis Zone. We would concur with this suggested derivation of $M$. thomasi, for it fits the known stratigraphic occurrences and requires only a slight increase in the proximal curvature of the rhabdosome, coupled with lessening of the thecal spacing and a slight tendency to metathecal isolation.

\section{ACKNOWLEDGEMENT}

Dr P.A. Jell, Museum of Victoria, made specimens of $M$. thomasi from Victoria available from the collections of the Museum. Penny Green assisted in preparation of the manuscript and Mr Fred Koolhof took the photographs. To these people we are grateful. 


\section{REFERENCES}

BARAGWANATH, W., 1925: The Aberfeldy district, Gippsland. Mem. Geol. Surv. Vict. 15: 19-22.

BERRY, W.B.N., 1964: Siluro-Devonian graptolites from Eildon, Victoria. Aust. J. Sci. 26: 223-224.

Churkin, M., Jaeger, H. \& Ererlein, G.D., 1970 Lower Devonian graptolites from southeastern Alaska Lethaea 3: 183-202.

Elles, G.L. In Lang, W.H. \& Cookson, I.C., 1985: On a flora including vascular land plants, associated with Monograptus, in rocks of Silurian age, from Victoria, Australia. Phil. Trans, R. Soc. Lond. 224: 421-449.

Garrat, M., 1983. Silurian and Devonian biostratigraphy of the Melbourne Trough, Victoria. Proc. R. Soc. Vict. 95: 77-98.

GarratT, M.J. \& Rickards, R.B., 1984: Graptolite biostratigraphy of early land plants from Victoria Australia. Proc. Yorkshire Geol. Soc. 44(4): 377-384.

Garratt, M.J. \& Rickards, R.B., 1987: Pridoli (Silurian) graptolites in association with Baragwanathia (Lycophytina). Bull. Geol. Soc. Denmark 35: 135-139.

HALL, T.S., 1906: Reports on graptolites. Rec. Geol. Surv. Vict. 1: 226-278.

HaLL, T.S., 1907: Reports on graptolites. Rec. Geol. Surv. Vict. 2: 137-143.

Harris, W.J. \& Thomas, D.E., 1937: Victorian graptolites (New Series), Part IV. Min. \& Geol. J. Vict. 1: $69-79$.

Howe, M.P.A., 1983: Measurement of thecal spacing in graptolites. Geol. Mag. 120: 635-638.

J ACKSOn, D.E., Lenz, A.C. \& Pedder, A.E.H., 1978; Late Silurian and Early Devonian graptolite, brachiopod, and coral faunas from Northwestern and Arctic Canada. Geol. Assoc. Can. Spec. Pap. 17: $1-159$.

JAEGER, H., 1966: Two late Monograptus species from Victoria, Australia, and their significance for dating the Baragwanathia flora. Proc. R. Soc. Vict. 79: 393-413, pls 41-43.

JAEGER, H., 1970: Remarks on the stratigraphy and morphology of Pragian and probably younger monograptids. Lethaia 3: 178-182.

JAEGER, H., 1973: About Lower Devonian Graptoloidea. Stratigrafiya nizhnego i srednego devona, Mezhdunar. Simp. Granitsa Silura Devona, Biostratigr. Silura, Nizhnego Srednego Devona., Tr. 3(2): 99-109.
JAEGER, H., 1988: Devonian graptolites. In DEVONIAN OF THE WORLD. Vol.II. Proc. Second Internat. Symp. on the Devonian System. Calgary, Canada: $431-438$

Keble, R.A., 1933: Middle Silurian land plants. Vict Nat. 49: 293-296, pl.

KOREN", T.N., 1979: Late monograptid faunas and the problem of graptolite extinction. Acta Pal. Pol. 24: $79-106$.

Lenz, A.C. \& JACKson, D.E., 1971a: Latest Silurian (Pridolian) and early Devonian Monograptus of Northwestern Canada. Bull. Geol. Surv. Can. 192: $1-25$.

LEnZ, A.C. \& JACKson, D.E., 197 !b: Preliminary investigations of the upper Silurian and lower Devonian graptolite biostratigraphy of the Northwestern Canadian mainland. Mezhdunar. Simp. Granitsa Silura Devona, Biostratigr. Silura, Nizhego Srednego Devona, Tr. 3(1): 127-134.

Mu, EN-ZHI \& Nr Yu-NAN, 1975: The Silurian and Devonian graptolites from the Qomolangma Feng Region. Report of Scientific Investigation in the Qomolangma Feng Region. Palaeontology, Fasc. 1. Sci. Press, Peking: 5-38

Ni Yu-NaN, 1985: In Mu, En-zhi \& Ni Yu-nan: Researches on the graptolites of Xizang (Tibet). Palaeontologia cathayana 2: $1-17$.

Porebska, E., 1984: Latest Silurian and early Devonian graptolites from Zdanow section, Bardo Mts (Sudetes). Ann. Soc. Geol. Pol. 52: 89-209.

Rickards, R.B. \& Banks, M.R., 1979: An Early Devonian monograptid from the Mathinna Beds, Tasmania. Alcheringa 3: 307-311.

Thomas, D.E., 1960: The zonal distribution of Australian graptolites. J. Proc. R. Soc. N.S.W. 94: 1-58.

WANG, X., 1977: The discovery of latest Silurian and early Devonian monograptids from Qinzhou, Guanxi and its (sic) significance. Acta Geol. Sin. 2: 190-205.

WANG, X., 1980: On the distribution, zonation and correlation of graptolite-bearing Silurian and early Devonian in China. Bull. Chin. Acad. Geol. Sci. 1(2) 23-36. 